\title{
Effectiveness and costeffectiveness of screening immigrants schemes for tuberculosis (TB) on arrival from high TB endemic countries to low TB prevalent countries
}

\author{
Sanneh A FNS, Al-Shareef AM \\ 1. University of Birmingham, Faculty of Public Health, Biostatistics and Epidemiology
}

\begin{abstract}
:
Background:

Immigrants to developed countries are a major source of TB. Therefore amongst strategies adopted for TB control in developed countries include; 1) Screening immigrants at ports of entry referred to as "Port of Arrival Screening" (PoA) and 2) Passive screening (PS) for TB which means screening immigrants through general practices, hospitals, chest-clinics and emergency departments. Evidence of the effectiveness and cost effectiveness of these strategies is not consistent.

Objective:

Evaluate efficiency of active PoA TB screening for immigrants from TB endemic-regions compared with Passive Screening of immigrant-populations from TB endemic-regions.

Methods:

Major electronic-databases and reference lists of relevant studies were searched. Experts of immigrants' TB screening were contacted for additional studies published or unpublished.

Systematic search of major databases identified only retrospective cohort-studies. Their qualities were assessed using Scottish Intercollegiate Guidelines Network (SIGN) methodological checklist for comparative cohort-studies.

\section{Results:}

Systematic electronic searches identified 1443 citations. Of these 74 studies were retrieved for evaluation against the review's inclusion/exclusion criteria (see study inclusion/exclusion criteria). Four studies met the inclusion criteria (figure 2) which were low in the evidence hierarchy of primary effectiveness studies and had heterogeneities between them. Thus descriptive data-synthesis was performed.

Proportionately PoA screening had the lowest percentage of receipt of tuberculin skin test (TST) and the highest percentage of non-attendance for TST reading (table 2). Active PoA screening reduced infectiousness by $34 \%$ compared to $30 \%$ by passive screening and new entrants screened at PoA were $80 \%$ less likely to be hospitalised Odds ratio (OR) $=0.2(95 \%$ confidence interval (CI) $0.1-0.2$ ).
\end{abstract}

Economic analysis:

One cost effectiveness analysis was found that compared the costs of; active PoA screening, general practice screening and homeless screening groups. The cost of detecting a case of TB were; $£ 1.26, £ 13.17$ and $£, 96.36$ for PS, homeless screening and active PoA screening respectively. The cost of preventing a case of TB were; $£ 6.32, £ 23.00$ and $£ 10.00$ for PS, homeless screening and PoA screening respectively, showing there is little difference between the different strategies.

\section{Conclussion:}

Active PoA screening is worth doing with significant benefits including early identification of risk groups with possible timely treatment/chemoprophylaxis intervention, prevention of transmission by significantly reducing infectiousness with subsequent avoidance of hospitalisation in active PoA screening group.

\section{http://dx.doi.org/10.4314/ahs.v14i3.23}

\section{Background}

Historically, human migration had had a major impact on the spread of infectious diseases such as TB 1. Early nineteenth century, it was estimated that $25 \%$ of deaths in Western Europe were attributable to TB 2. Through travel TB spread to different parts of the world resulting in major epidemics in parts of sub-Saharan and central

\section{Corresponding author:}

Abdoulie F.N.S. Sanneh,

P.O.bOX 5242,

Brikama town,

Kombo Central,

Western Division, the Gambia, West Africa.
Africa, South-East Asia and the Americas 2. Following improvements in housing, nutrition and discoveries in antibiotics in the 1950s, incidence of TB fell in Western Europe and North America 1. However incidence continued to rise in resource-limited-settings3.

In the face of globalisation with western economies booming, availability of cheap travel, political instability, man-made and natural disasters in less developed countries compounded by economic hardship, economic migration to the industrialised world has increased tremendously 4, majority of who come from high TB endemic-regions 5. Accordingly research evidence supports that migrants from TB endemic-countries con- 
tinue to have relatively high rates of latent TB for years after arrival in low TB prevalence countries 6,7. However a study of the transmission rates of mycobacterium (M) TB amongst different populations in Norway 8 to determine the genetic diversity of the population of $\mathrm{M}$. TB isolates in TB patients and the degree of clustering of $\mathrm{M}$. TB detected relatively little TB transmission from foreign-born residents to the general population. But there is consistent evidence that incidence of TB is higher amongst foreign-born ethnic-minority populations than native born-populations in the west; United States (US) 9, United Kingdom (UK) 10, Canada 11 and Switzerland 12. It was against this background in the late 20th century, some industrialised countries instituted port of entry TB screening for immigrants from high TB incidence regions; UK5,16,27, US15,18 and Canada11. However evidence of the effectiveness and cost effectiveness of new entrants' TB screening is inconsistent. It had been shown to be; effective 13,14,15, both effective and cost effective 16 but some researchers suggested no evidence of effectiveness 17,18,19 implying inconsistent public health research evidence for compulsory TB screening of new immigrants. Thus, this review reviewed the effectiveness and cost effectiveness of new entrants' TB screening schemes for immigrants from TB endemic regions to low TB prevalent countries.

\section{Epidemiology}

It has been estimated that of the one third of the world's population infected with TB, 8 million developed active TB with 5000 deaths each day; 1.5 million occurred in Sub-Saharan Africa, 3 million in South-East Asia and over a quarter of a million in Eastern Europe 20.

England like many industrialised countries where new entrants screening for TB is being practised on arrival, risk of TB is significantly higher in ethnic-minority groups; the crude incidence of active TB in native-born population in 1998 was 4.4/100 000 compared with 121-210/100 000 in ethnic-minorities 21. Similar evidence was supported in California 22 and Montreal 23. In England trends showed that TB rates peaked in early twentieth century with incidence of 300/100 000 per year which declined to 10/100 000 in 1987 . The rates then fluctuated until 2007 with 14/100 000 population. However this represented a small increase of $0.7 \%$ compared with 200624.

Current Service Provision (UK)

In the UK new entrants TB screening guidelines were adapted from the national recommendations 5 by the government's independent health watchdog (NICE). Figure 1 shows a typical pathway for the screening of new entrants.

On arrival new entrants from regions with TB preva-

Figure 1 - Pathway for screening new entrants

Figure 1

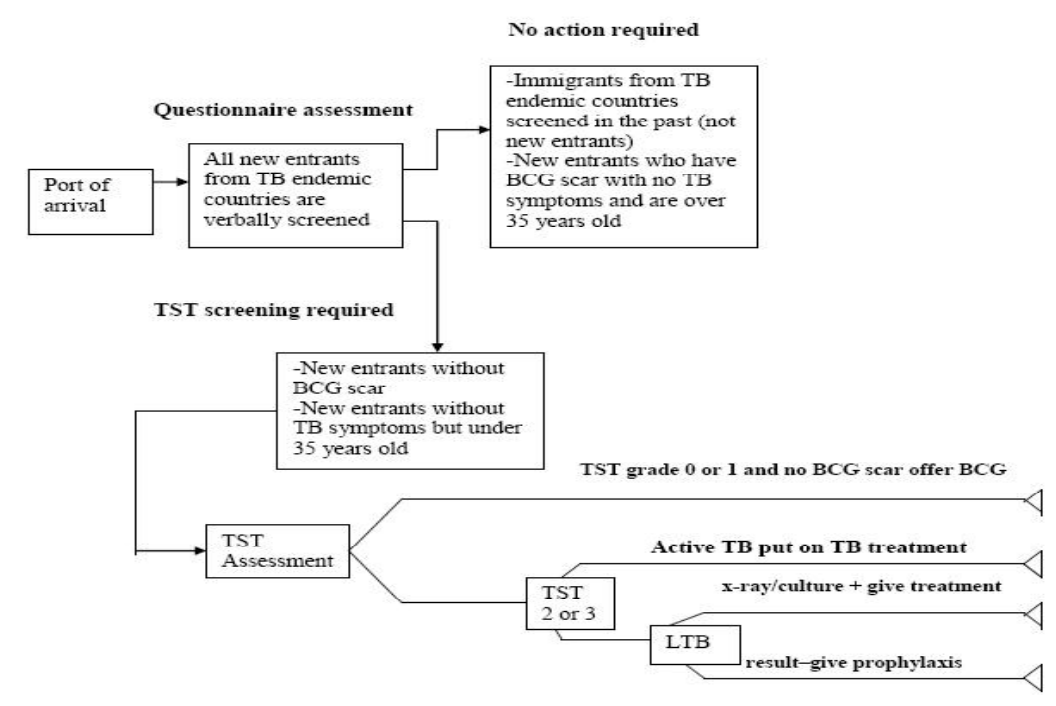

lence of $>/=40 / 100000$ are screened verbally using a simple questionnaire. If no evidence of TB was found and the person has BCG scar, no action is taken. All new entrants under 35 years and those without BCG scar are subjected to TST test. If the test is negative (grades 0 or 1 ) they are offered BCG vaccination. If the test is positive (grades 2 or above) with/without 
signs and symptoms they are given anti-TB treatment/ chemoprophylaxis respectively. However if the test is less reliable, they should be considered for interferongamma immunological testing if available. On the other hand if the test is not conclusive, the person is referred for further investigations using chest $\mathrm{x}$-ray/culture. If the result is consistent with active TB they are put on anti-TB treatment.

\section{Description of Interventions}

Any TB screening schemes instituted at PoA for new entrants from TB endemic-regions intending to stay in low TB prevalent country for at least six-months. The review aims to look at efficiency of the different schemes from host country's government perspective. Therefore any studies that investigated the effectiveness of screening subjects in their own countries were excluded because costs of such screening schemes are borne by subjects or their governments.

\section{Methodology for the Identification of Effectiveness} Studies

A comprehensive systematic search of the general bibliographic databases; MEDLINE, EMBASE and PUBMED was conducted in June 2008. The data sources and periods covered were;

-MEDLINE from 1950 - 2008

-EMBASE from 1977 - 2008

-PUBMED and COCHRANE library databases with no date limits. The search strategies used are available on request.

-TB journals and websites eg. International union against TB (IUATB), Thorax, World health organisation (WHO) and internet searches using Google search engines.

-Reference lists of studies thought to be relevant to the review were scanned for any additional studies.

-Experts in new immigrants' screening were contacted for relevant information and knowledge of unpublished work on the subject.

Study Inclusion/Exclusion Criteria

Every retrieved citation was checked against a predetermined inclusion/exclusion criteria form (available on request). One reviewer (AS) checked the title and abstract of every article, which were independently verified by the second reviewer (MA). Any disagreement was discussed and consensus was achieved. The following shows the population, intervention, comparator and outcomes (PICO) of included studies;

Population: Immigrants from TB endemic-regions with TB prevalence of $>/=40 / 100000$ population as recommended by British Thoracic Society 5 .
Intervention: (See description of intervention). Studies were excluded if they had an inappropriate/no comparator arm in the study.

Comparator: PS of immigrants' populations from TB endemic-regions through general practitioners and other modes of routine practice. It was considered for patients who had sought medical consultation either due to signs/symptoms of TB irrespective of prior screening history or for some other condition during which TB was accidentally diagnosed.

Outcome Measures of Interest:

-BCG vaccinations and chemoprophylaxis treatment prior and after screening respectively

-Number of latent and active TB cases detected

-Treatment outcomes of active TB; cured, treatment complete, died, failed, defaulted and transferred out defined according to WHO guideline 25.

Study Design: For inclusion, studies must be of the following designs;

-Cluster randomised trial

-Prospective cohort studies and

-Retrospective cohort studies

Quality Assessment

Two reviewers (AS and MA) independently quality assessed the included studies using the quality assessment methodological checklist for cohort studies 26, in order to minimise bias and errors in the conduct and analysis of primary studies. The criteria used to decide whether a study was of very good quality, good quality or poor is given below;

1. If the study met all important characteristic quality attributes : very good

2. If the study inadequately reported one or more of the quality attributes : good

3. If the study did not met one or more quality attributes : poor

NB: See study quality for the quality attributes

Any disagreement was discussed and consensus achieved. A detail quality assessment methodological checklist is available on request.

Data Extraction

Using a predetermined data extraction form that was piloted on a sample of studies, one reviewer (AS) extracted the data presented in tabular forms (table 1 and 2).This allowed comparison between different studies in the evaluation of the effectiveness of the interventions in the studies. Extracted data was independently verified by MA. Any disagreement was discussed and consensus achieved.

Results of Included Effectiveness Studies 
Number of Studies Identified: 1443 citations were identified from the initial electronic searches. Of these 74 studies were retrieved for evaluation against the review's inclusion/exclusion criteria. 70 studies were excluded. Four retrospective cohort studies were included shown in figure 2. There were no cluster-randomised or pro- spective cohort studies. This may be reasonable given the risk and practical challenges of random allocation of people at high risk of TB to a non-intervention on entry. The studies have common objective, applied the same inclusion/exclusion criteria but reported different outcome measures.

Figure 2 - QUORUM FLOWCHART SHOWING STUDY SELECTION PROCESS OF PRIMARY EFFECTIVENESS STUDIES

Figure 2

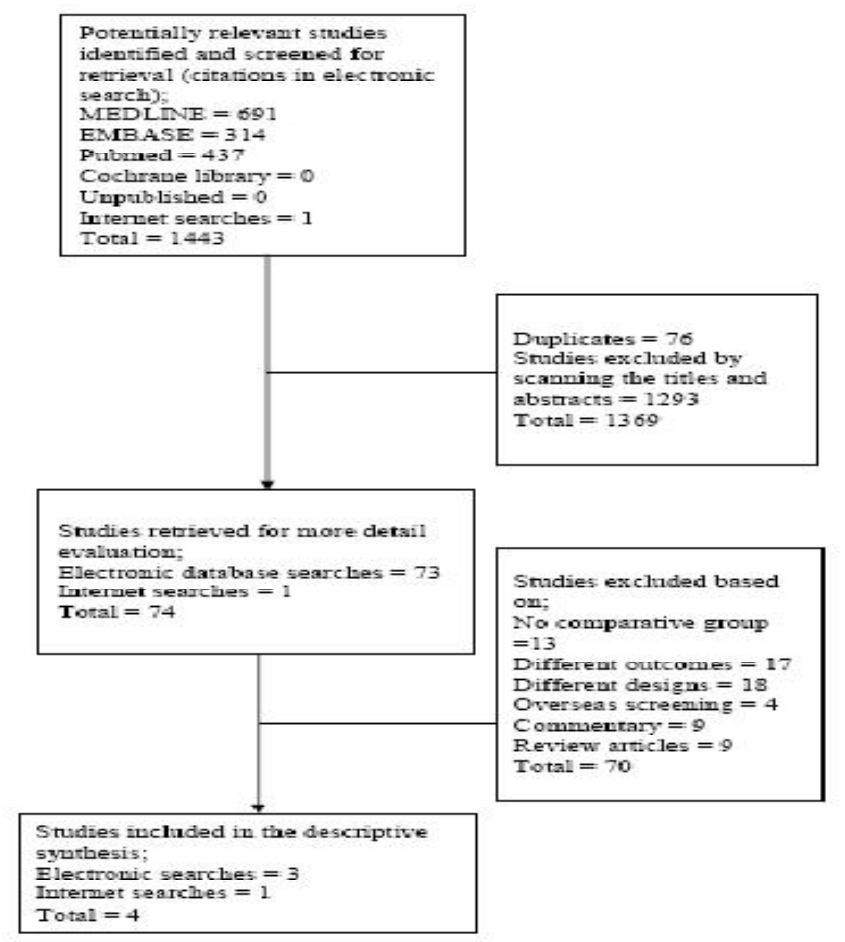

Study Quality

Qualities of the studies were unanimously agreed as poor by the two reviewers, given the following reasons;

- They were of design which is lower in the evidence-based hierarchy for effectiveness studies

- Only Ormerod study reported total number of study population and effect size in the comparator group

- There were high rates of non-respondents in the studies; Bothamley et al and Ormerod

- Only Monney et al considered the validity and reliability of the assessment tools used

- $\quad$ Ormerod and Verver et al did not report total number of study participants

- $\quad$ All failed to report the relative risk which would have been helpful in assessing the risk of TB in the groups with significant heterogeneities.

Studies' Characteristics

Four studies met the inclusion criteria that were all retrospective cohort studies. The details of these studies and populations are provided in table 1 . The results of included studies are presented in tabular forms; 


\begin{tabular}{|c|c|c|c|c|c|c|c|}
\hline \multirow{4}{*}{\begin{tabular}{|l|} 
Study \\
Bothamley et al \\
(2002)
\end{tabular}} & \multirow{4}{*}{\begin{tabular}{|l|} 
Study design \\
Retrospective \\
cohort study
\end{tabular}} & \begin{tabular}{|l|} 
Country \\
\end{tabular} & Sex & & Age (median age) & & Study population \\
\hline & & \multirow[t]{3}{*}{\begin{tabular}{|l} 
United \\
Kingdom
\end{tabular}} & \multirow{3}{*}{\multicolumn{2}{|c|}{ Not specified }} & \multirow{3}{*}{\multicolumn{2}{|c|}{$\begin{array}{l}\text { Not specified. However for port of arrival group; } 87 \\
(37 \%) \text { were age }<16 \text { and } 28(12 \%) \text { were age }>35 . \\
\text { Therefore } 120(51 \%) \text { were }>16 \text { years but }<35 \text { years }\end{array}$}} & $\begin{array}{l}\text { Port of arrival = } \\
1262\end{array}$ \\
\hline & & & & & & & Homeless $=172$ \\
\hline & & & & & & & $\begin{array}{l}\text { General practice not } \\
\text { reported }\end{array}$ \\
\hline \multirow[t]{2}{*}{ Monney et al (2005) } & \multirow[t]{2}{*}{$\begin{array}{l}\text { Retrospective } \\
\text { cohort study }\end{array}$} & \multirow[t]{2}{*}{ Switzerland } & \multirow[t]{2}{*}{$\begin{array}{l}\text { Active screening } \\
\text { Female }=21 \% \\
\text { Male }=79 \%\end{array}$} & \multirow[t]{2}{*}{$\begin{array}{l}\text { Passive } \\
\text { screening } \\
\text { Female }=37 \\
\% \\
\text { Male }=63 \%\end{array}$} & \multirow[t]{2}{*}{$\begin{array}{l}\text { Active screening } \\
\text { Median age }=26 \text { (for } \\
\text { females) } \\
\text { Median age for male not } \\
\text { given }\end{array}$} & \multirow{2}{*}{$\begin{array}{l}\text { Passive screening } \\
\text { Median age for female } \\
\text { foreign workers* }=34 \\
\text { Median age for female } \\
\text { other** = } 31 \\
\text { Median age for Swiss } \\
\text { female citizens }=64\end{array}$} & $\begin{array}{l}\text { Active screening }= \\
13,507\end{array}$ \\
\hline & & & & & & & $\begin{array}{l}\text { Passive screening not } \\
\text { reported }\end{array}$ \\
\hline \multirow[t]{2}{*}{ Ormerod (1990) } & \multirow[t]{2}{*}{$\begin{array}{l}\text { Retrospective } \\
\text { cohort study }\end{array}$} & \multirow[t]{2}{*}{$\begin{array}{l}\text { United } \\
\text { Kingdom }\end{array}$} & \multirow{2}{*}{\multicolumn{2}{|c|}{ Not specified }} & \multirow{2}{*}{\multicolumn{2}{|c|}{$\begin{array}{l}\text { Age distribution was not specified. However } 1379 \text { were } \\
\text { under the age of } 30 \text { years and } 312 \text { were either }</=15 \\
\text { years or }>30 \text { years for those screened }\end{array}$}} & $\begin{array}{l}\text { Active port of entry } \\
\text { screening }=1,085\end{array}$ \\
\hline & & & & & & & $\begin{array}{l}\text { Passive screening = } \\
948\end{array}$ \\
\hline \multirow[t]{2}{*}{ Verver et al (2001) } & \multirow[t]{2}{*}{$\begin{array}{l}\text { Retrospective } \\
\text { cohort study }\end{array}$} & \multirow[t]{2}{*}{ Netherlands } & \multirow[t]{2}{*}{$\begin{array}{l}\text { Active screening } \\
\text { Female = } 165 \\
(36 \%) \\
\text { Male }=289(64 \%)\end{array}$} & \multirow{2}{*}{\begin{tabular}{|l} 
Passive \\
screening \\
Female = \\
$137(37 \%)$ \\
Male = \\
$231(63 \%)$
\end{tabular}} & \multirow[t]{2}{*}{$\begin{array}{l}\text { Active screening } \\
\text { Most common age range } 25 \\
-34 \text { (for both sexes) }\end{array}$} & \multirow[t]{2}{*}{$\begin{array}{l}\text { Passive screening } \\
\text { Most common age range } \\
25-34 \text { (for both sexes) }\end{array}$} & $\begin{array}{l}\text { Active screening = } \\
454\end{array}$ \\
\hline & & & & & & & $\begin{array}{l}\text { Passive screening = } \\
368\end{array}$ \\
\hline
\end{tabular}

Attendance for TB Screening (Bothamley et al, 2002): Of the four studies, Bothamley et al that assessed attendance for screening invitation showed active PoA had a smaller proportion of attendance for screening upon invitation compared with passive screening. Although a good proportion of PoA received TST, it was lower than that of passive screening. In terms of failure to attend reading of the TST, active PoA had the high- est percentage shown in table 2 . There were no significant tests for these differences. However in the group of homeless that comprised of both recent immigrants and local residents, attendance for reading of the TST was lower in the recent immigrants which was statistically significant; $26.2 \%$ and $45.6 \%$ respectively (chisquared $=10.1$ with $\mathrm{p}<0.01$ ).

Table 2

TABLE 2: Attendance for TB Screening

\begin{tabular}{|c|c|c|c|c|c|}
\hline & \multicolumn{5}{|c|}{ Different models of TB screening for immigrants } \\
\hline Details & \multicolumn{2}{|c|}{ Port of arrivals } & \multicolumn{2}{|c|}{ General practice } & Homeless \\
\hline Invited for screening & \multicolumn{2}{|l|}{1262} & \multicolumn{2}{|l|}{ unknown } & 172 \\
\hline $\begin{array}{l}\text { Responded to } \\
\text { invitation }\end{array}$ & \multicolumn{2}{|c|}{235 (18.6\%) } & \multicolumn{2}{|l|}{45} & $172(100 \%)$ \\
\hline Received TST & \multicolumn{2}{|l|}{$181(77 \%)$} & \multicolumn{2}{|l|}{39 (86.7\%) } & $172(100 \%)$ \\
\hline $\begin{array}{l}\text { Non attendance for } \\
\text { TST reading }\end{array}$ & \multicolumn{2}{|l|}{$54(29.8 \%)$} & \multicolumn{2}{|l|}{$9(23.1)$} & $45(26.2 \%)$ \\
\hline \multicolumn{6}{|c|}{ BCG vaccination and chemoprophylaxis administration } \\
\hline & \multicolumn{2}{|c|}{ Bothamley et al 2002} & \multicolumn{3}{|l|}{ Ormerod 1990} \\
\hline Details & PoA & GP & Homeless & PoA & GP \\
\hline Study population & 1262 & Unknown & 172 & 1085 & 948 \\
\hline Received TST & 181 & 39 & 172 & 1085 & 948 \\
\hline Offered BCG & $18(14.2 \%)$ & $14(46.7 \%)$ & 29 (16.9\%) & \multicolumn{2}{|c|}{413 (29.9\%) } \\
\hline Received BCG & 18 (100\%) & $14(100 \%)$ & $27(93.1 \%)$ & \multicolumn{2}{|c|}{$413(100 \%)$} \\
\hline $\begin{array}{l}\text { Started } \\
\text { chemoprophylaxis }\end{array}$ & $6(4.7 \%)$ & $8(26.7 \%)$ & $11(6.4 \%)$ & \multicolumn{2}{|c|}{$40 / 322$ (12.4\%) } \\
\hline $\begin{array}{l}\text { Finished } \\
\text { chemoprophylaxis }\end{array}$ & 5 (83.3\%) & $2(25 \%)$ & $6(54.5 \%)$ & \multicolumn{2}{|c|}{ Not reported } \\
\hline
\end{tabular}


BCG Vaccinations and Chemoprophylaxis Administrations: Bothamley et al and Ormerod studies assessed these outcomes. The highest proportion of immigrants offered BCG vaccination in Bothamley was in the general practice. However 100\% of both active PoA and general practice offered BCG received it, whilst $93.1 \%$ in the homeless group received it. In Ormerod study this outcome was not classified into groups. Nonetheless $29.9 \%$ that required BCG received it $(240 / 1000)$. Outcome of chemoprophylaxis treatment was not as- sessed. But in Bothamley et al, the proportion that started it was highest in the passive screening group. Whilst in Ormerod study chemoprohylaxis was offered to $12.4 \%$. Outcomes presented in table 2 above.

Latent and Active Cases of TB: Proportion of latent TB cases was highest in the active screening groups of two of the three studies that reported them (Monney et al and Verver et al). But proportions of active TB cases were consistently higher in the passive group in three out of the four studies (Monney et al, Ormerod and Verver et al) as shown in table 3.

Table 3 - Outcomes of Screening; Latent and Active Cases of TB Detected in the Various Studies

\begin{tabular}{|c|c|c|c|c|c|c|c|c|c|}
\hline \multirow[b]{2}{*}{$\begin{array}{l}\text { Study } \\
\text { details }\end{array}$} & \multicolumn{3}{|c|}{ Bothamley et al 2002} & \multicolumn{2}{|c|}{ Monney et al 2005} & \multicolumn{2}{|c|}{ Ormerod 1990} & \multicolumn{2}{|c|}{ Verver et al 2001} \\
\hline & $\begin{array}{l}\text { Active } \\
\text { screening } \\
\text { (PoA) }\end{array}$ & $\begin{array}{l}\text { Passive } \\
\text { screening } \\
\text { (GP) }\end{array}$ & $\begin{array}{l}\text { Passive } \\
\text { screening } \\
\text { (Homeless) }\end{array}$ & $\begin{array}{l}\text { Active } \\
\text { screening } \\
\text { (PoA) }\end{array}$ & $\begin{array}{l}\text { Passive } \\
\text { screening }\end{array}$ & $\begin{array}{l}\text { Active } \\
\text { screening } \\
\text { (PoA) }\end{array}$ & $\begin{array}{l}\text { Passive } \\
\text { screening }\end{array}$ & $\begin{array}{l}\text { Active } \\
\text { screening } \\
\text { (PoA) }\end{array}$ & $\begin{array}{l}\text { Passive } \\
\text { screening }\end{array}$ \\
\hline $\begin{array}{l}\text { Study } \\
\text { population }\end{array}$ & 1262 & $\begin{array}{l}\text { Not } \\
\text { reported }\end{array}$ & 172 & 15519 & $\begin{array}{l}\text { Not } \\
\text { reported }\end{array}$ & 1085 & 948 & $\begin{array}{l}\text { Not } \\
\text { reported }\end{array}$ & $\begin{array}{l}\text { Not } \\
\text { reported }\end{array}$ \\
\hline $\begin{array}{l}\text { Total } \\
\text { screened }\end{array}$ & 235 & 45 & 172 & 13507 & $\begin{array}{l}\text { Not } \\
\text { reported }\end{array}$ & \multicolumn{2}{|c|}{$\begin{array}{l}1691 \text { did not specify the } \\
\text { total for either scheme }\end{array}$} & $\begin{array}{l}\text { Not } \\
\text { reported }\end{array}$ & $\begin{array}{l}\text { Not } \\
\text { reported }\end{array}$ \\
\hline Latent TB & $\begin{array}{l}6(5 \% \text { of } \\
\text { attendees } \\
\text { for reading } \\
\text { of TST = } \\
(6 /(181- \\
\left.154))^{*} 100\right)\end{array}$ & $\begin{array}{l}8(27 \% \text { of } \\
\text { attendees } \\
\text { for reading } \\
\text { of } \\
\text { TST }=(8 /(39 \\
-9)) * 100)\end{array}$ & $\begin{array}{l}11(9 \% \text { of } \\
\text { attendees } \\
\text { for reading } \\
\text { of } \\
\text { TST=(11/(1 } \\
72- \\
45)) * 100)\end{array}$ & $\begin{array}{l}16(31 \% \text { of } \\
51 \text { new } \\
\text { cases) }\end{array}$ & $\begin{array}{l}20(25 \% \text { of } \\
81 \text { new } \\
\text { cases) }\end{array}$ & \multicolumn{2}{|c|}{ Not reported } & $\begin{array}{l}99(62 \% \text { of } \\
159)\end{array}$ & $\begin{array}{l}48(45 \% \text { of } \\
107)\end{array}$ \\
\hline Active TB & 3 & $\begin{array}{l}\mathrm{O}(\mathrm{O} \% \text { of } \\
\text { attendees } \\
\text { for reading } \\
\text { of TST) }\end{array}$ & $\begin{array}{l}\mathrm{O}(\mathrm{O} \% \text { of } \\
\text { attendees } \\
\text { for reading } \\
\text { of TST) }\end{array}$ & $\begin{array}{l}35(69 \% \text { of } \\
51 \text { new } \\
\text { cases) }\end{array}$ & $\begin{array}{l}61(75 \% \text { of } \\
81 \text { new } \\
\text { cases) }\end{array}$ & 11 & 19 & $\begin{array}{l}60(38 \% \text { of } \\
159)\end{array}$ & $\begin{array}{l}59(55 \% \text { of } \\
107)\end{array}$ \\
\hline Effect size & $\begin{array}{l}\text { (point } \\
\text { incidence) } \\
1546 / 100 \\
\text { 000 }\end{array}$ & - & - & $\begin{array}{l}\text { (Incidence) } \\
525 / 100 \\
000\end{array}$ & - & $\begin{array}{l}\text { (incidence) } \\
65 / 1000\end{array}$ & & \multicolumn{2}{|c|}{$\begin{array}{l}\text { Odds ratio }=0.595 \% \mathrm{Cl} \\
(0.3-0.8)\end{array}$} \\
\hline
\end{tabular}

Treatment Outcomes for TB Cases: Percentage of cured was consistently higher in the active PoA screening. But percentage of treatment completion was higher

Table 4 - Outcome of treatment for latent and active TB cases in the passive screening groups. The other treatment outcomes; failures, deaths, defaulters and transferred were not reported or inconsistent as presented in table 4.

\begin{tabular}{|c|c|c|c|c|}
\hline \multirow[b]{2}{*}{ Study details } & \multicolumn{2}{|l|}{ Monney et al 2005} & \multicolumn{2}{|l|}{ Verver et al 2001} \\
\hline & Active screening & $\begin{array}{l}\text { Passive } \\
\text { screening }\end{array}$ & Active screening & $\begin{array}{l}\text { Passive } \\
\text { screening }\end{array}$ \\
\hline $\begin{array}{l}\text { Proportion of TB cases } \\
\text { that received treatment }\end{array}$ & $\begin{array}{l}\text { Active screening }=51 \\
\text { cases }(100 \%)\end{array}$ & $\begin{array}{l}\text { Passive screening }=81 \\
\text { cases }(100 \%)\end{array}$ & $\begin{array}{l}\text { Active screening }=454 \\
(100 \%)\end{array}$ & $\begin{array}{l}\text { Passive screening }=368 \\
(100 \%)\end{array}$ \\
\hline Cured & $\begin{array}{l}\text { Active screening } \sim 13 \\
(25 \%)\end{array}$ & $\begin{array}{l}\text { Passive screening } 15 \\
(19 \%)\end{array}$ & $\begin{array}{l}\text { Active screening }=139 \\
(31 \%)\end{array}$ & $\begin{array}{l}\text { Passive screening }=83 \\
(23 \%)\end{array}$ \\
\hline Completed treatment & $\begin{array}{l}\text { Active screening } 30 \\
(59 \%)\end{array}$ & $\begin{array}{l}\text { Passive screening } 49 \\
(61 \%)\end{array}$ & $\begin{array}{l}\text { Active screening }=245 \\
(54 \%)\end{array}$ & $\begin{array}{l}\text { Passive screening }=210 \\
(57 \%)\end{array}$ \\
\hline Failure & Active screening $\sim 2(3 \%)$ & Passive screening $~ 1(1 \%)$ & Not reported & Not reported \\
\hline Dead & Active screening $\sim \mathrm{O}(0 \%)$ & Passive screening $\sim 6(8 \%)$ & Active screening $=0(0 \%)$ & Passive screening $=2(1 \%)$ \\
\hline Default & Active screening $2(3 \%)$ & Passive screening 6(8\%) & $\begin{array}{l}\text { Active screening = } \\
47(10 \%)\end{array}$ & $\begin{array}{l}\text { Passive screening = } \\
36(10 \%)\end{array}$ \\
\hline Transferred & Active screening $~ 5(10 \%)$ & Passive screening 2(3\%) & Active screening $=22(5 \%)$ & $\begin{array}{l}\text { Passive screening = } \\
27(7 \%)\end{array}$ \\
\hline
\end{tabular}

NB: Percentages and figures for column 2 in table 4 above are estimates (rounded up or down) derived from graph in which the authors presented the treatment outcomes without actual figures

Further Investigations: The outcomes of further investigations that resulted in the diagnosis of active cases of TB were consistently higher in the active PoA screening as shown in table 5. However Ormerod study did not report the outcome of follow up investigations.

Table 5 
Table 5: Further Investigations

\begin{tabular}{|c|c|c|c|c|c|c|c|c|c|}
\hline & \multicolumn{3}{|c|}{ Bothamley et al 2002} & \multicolumn{2}{|c|}{ Monney et al 2005} & \multicolumn{2}{|c|}{ Ormerod 1990} & \multicolumn{2}{|c|}{ Verver et al 2001} \\
\hline $\begin{array}{l}\text { Study } \\
\text { details }\end{array}$ & $\begin{array}{l}\text { Active } \\
\text { screening } \\
\text { (PoA) }\end{array}$ & $\begin{array}{l}\text { Passive } \\
\text { screening } \\
\text { (GP) }\end{array}$ & $\begin{array}{l}\text { Passive } \\
\text { screening } \\
\text { (Homeless) }\end{array}$ & $\begin{array}{l}\text { Active } \\
\text { screening } \\
\text { (POA) }\end{array}$ & $\begin{array}{l}\text { Passive } \\
\text { screening }\end{array}$ & $\begin{array}{l}\text { Active } \\
\text { screening } \\
\text { (PoA) }\end{array}$ & $\begin{array}{l}\text { Passive } \\
\text { screening }\end{array}$ & $\begin{array}{l}\text { Active } \\
\text { screening } \\
\text { (POA) }\end{array}$ & $\begin{array}{l}\text { Passive } \\
\text { screening }\end{array}$ \\
\hline $\begin{array}{l}\text { Total } \\
\text { follow ups }\end{array}$ & 107 & 22 & 97 & 51 & 63 & 9 & $\begin{array}{l}\text { Not } \\
\text { reported }\end{array}$ & \multicolumn{2}{|c|}{$\begin{array}{l}321 \text { (both active and } \\
\text { passive groups) }\end{array}$} \\
\hline $\begin{array}{l}\text { Loss to } \\
\text { follow ups }\end{array}$ & $\begin{array}{l}\text { Not } \\
\text { reported }\end{array}$ & None & $2(2.1 \%)$ & None & None & $\begin{array}{l}\text { Not } \\
\text { reported }\end{array}$ & $\begin{array}{l}\text { Not } \\
\text { reported }\end{array}$ & \multicolumn{2}{|c|}{$\begin{array}{l}55 \text { ( } 17.1 \% \text { both active } \\
\text { and passive groups) }\end{array}$} \\
\hline $\begin{array}{l}\text { Number of } \\
\text { TB cases }\end{array}$ & $3(2.8 \%$ & $0 \%$ & $0 \%$ & $24(47.1 \%)$ & $20(31.7 \%)$ & Unknown & unknown & & \\
\hline \multicolumn{10}{|c|}{ Symptom complaints and duration at diagnosis } \\
\hline & \multicolumn{4}{|c|}{ Monney et al 2005} & \multicolumn{5}{|c|}{ Verver et al 2001} \\
\hline & \multicolumn{2}{|c|}{ Active screening } & \multicolumn{2}{|c|}{ Passive screening } & \multicolumn{2}{|c|}{ Active screening } & \multicolumn{3}{|c|}{ Passive screening } \\
\hline $\begin{array}{l}\text { Proportion } \\
\text { reporting } \\
\text { symptoms } \\
\text { at } \\
\text { diagnosis }\end{array}$ & \multicolumn{2}{|l|}{$50.7 \%$} & \multicolumn{2}{|l|}{$82.4 \%$} & \multicolumn{2}{|l|}{$37 \%$} & \multicolumn{3}{|c|}{ Not reported } \\
\hline \multirow{2}{*}{$\begin{array}{l}\text { Mean(med } \\
\text { ian) } \\
\text { duration of } \\
\text { symptoms } \\
\text { before } \\
\text { diagnosis }\end{array}$} & \multicolumn{2}{|c|}{$\begin{array}{l}2 \text { months (at least } \\
8 \text { weeks) }\end{array}$} & \multirow{2}{*}{\multicolumn{2}{|c|}{$\begin{array}{l}2.5 \text { months (at least } \\
10 \text { weeks) }\end{array}$}} & \multicolumn{2}{|c|}{4.2 (O weeks) } & \multirow{2}{*}{\multicolumn{3}{|c|}{10.5 ( 7.5 weeks) }} \\
\hline & \multicolumn{2}{|c|}{ No significance test reported } & & & \multicolumn{2}{|c|}{ P-value $<0.001$} & & & \\
\hline
\end{tabular}

Duration of Symptoms Complaints, Period of Infectiousness and Hospitalisations: The percentages of people that did not complain of symptoms at diagnosis in Monney et al were 49.3\% (95\% CI 37.4\% - 61.2\%) and $17.6 \%(95 \%$ CI $10.3 \%-24.9 \%)$ in active and passive screening groups respectively. When analysis was limited to cases confirmed following further investigations and smear positives, they were; $42.2 \%$ (95\% CI $27.2 \%-57.2 \%), 13 \%(95 \%$ CI $5.31 \%-20.7 \%)$ and $22.2 \%$ (95\% CI $9.6 \%$ - 34.8\%), $11.7 \%$ (95\% CI 4.4\% $19.0 \%)$ in active PoA and passive screening respectively. This information is summarised in table 5 above.

The duration of symptoms complaints at diagnosis in the active PoA and PS in Verver et al were; 4.2 weeks and 10.5 weeks respectively ( $\mathrm{p}$-value $<0.001$ ). The active PoA screening reduced the total infectious period by $34 \%$ compared to $30 \%$ by PS. New entrants screened at PoA were $80 \%$ less likely to be hospitalised, $\mathrm{OR}=0.2$ (95\% CI $0.1-0.2)$.

Heterogeneity between Results of Included Studies

A detail analysis of the data proved that quantitative meta-analysis was not appropriate. The reasons include; -Inconsistent use of TB screening tools resulting in methodological and clinical heterogeneities; use of different screening questionnaire tools, targeting of high risk groups

-Varying lengths of study periods resulting in either improvement or deterioration of TB programmes conditions either in the host country or applicant's

-Use of different effect sizes and missing data.

\section{Methods for Economic Analysis}

The search for cost studies for this systematic review was based on a predefined study selection form available on request with search strategies and study selection process.

669
Results for Economic Analysis: One economic evaluation study was found. This was an embedded cost effectiveness analysis in one of the included effectiveness studies (Bothamley et al, 2002).

Critique of Economic Study: The objective of the study was to assess the yield of screening in 3 screening schemes; active PoA screening, screening in GP and screening of a group of homeless. The perspective was not clearly stated. However it can be assumed that a national healthcare payer perspective was adapted because the government is the provider of all the alternatives and seems to have been conducted against the background that active PoA screening scheme has a poor yield and has been considered not effective 27 .

The study examined both costs and effects. The effects examined were; the cost per person screened per case and the cost per person screened per case of TB prevented and the cost effectiveness was determined as savings or benefits gained in one scheme compared with the other alternatives. However a threshold for effectiveness was not determined. Taking a National Health Service perspective, the analysis considered enough of the costs and consequences of TB screening including further investigations (table of the costs available on request). However capital/overhead and clerical costs were not available for GP. Indirect costs; transportation, TST reading, intangible and non-attendance were not included.

The costs were measured in pound-sterling and to aid comparison of cost of the different schemes at different locations, authors chose an index of cost/person screened per case of TB prevented which allowed them to combine the outcomes of interest; BCG vaccination, prevention, treatment and diagnosis of TB. Incidence of TB was left in its natural unit which was appropriate to do.

African Health Sciences Vol 14 Issue 3, September 2014 
No discounting despite the benefits of TB prevention could go beyond one year. Although the study showed GP screening was most cost effective (table 6), sensitivity analysis to investigate the effect of identifying a case of TB showed that the benefit of screening was highly sensitive to the number of cases of TB identified and case holding during treatment. However authors did not calculate any incremental cost effectiveness ratio.

\section{Discussion}

The objective of this review was to assess the efficiency of active PoA TB screening for new entrants compared with PS. Four poor quality retrospective cohort-studies met the review's inclusion criteria. In terms of some outcome measures of interest; BCG and chemoprophylaxis interventions and treatment outcomes were not consistently reported. However all studies reported these outcomes; number of latent and active cases of TB.

PoA screening had the highest proportion of invitees for TB screening and easily identified at risk groups due to their exposure status and offered them chemoprophylaxis and BCG. However they had lower proportion of respondents and attendance to screening test. In terms of detections of latent and active TB cases, three out of the four studies showed that proportions of both cases have been consistently higher in PS groups. However proportions of latent and active TB cases detected by screening were higher in active PoA and PS groups of two studies; Verver et al and Bothamley et al respectively.

Treatment outcomes were reported by two studies; these outcomes were available for $72 \%$ and $75 \%$ of cases that received treatment in active and passive screening groups respectively in Monney et al whilst treatment outcomes were available for $100 \%$ of notifications in Verver et al. Active PoA detected TB earlier when it was drug-sensitive with higher cure rates, however higher proportions of treatment completion and mortalities were in passive screening groups. These could be due to the long period of treatment during which immigrants change addresses frequently until they find a settled home and passive screening might had detected more severe cases not drug-sensitive.

Assessment of outcomes of further investigations was not assessed in primary studies. However it was shown to be higher in the PoA. Given that in some countries qualification for a residence/work permit is linked to full assessment of immigrants TB status (Monney et al and Verver et al). This could be an encouragement for immigrants to comply with further investigations.

In terms of signs and symptoms complaints, duration of symptoms complaints was statistically significantly lower in active PoA screening groups. Subsequently this correlates with statistically significantly fewer numbers of hospitalisations in the active PoA.

One economic evaluation study was found, a cost effectiveness analysis of new entrants TB screening (Bothamley et al). The study showed that PS in general practice was most cost effective as the cost for screening immigrants in general practice, homeless and at PoA were; $f 1.26, £, 13.17$ and $f, 96.36$ respectively and the cost per person screened per case of TB prevented were; $£ 6.32, £ 23.00$ and $£, 10.00$ respectively.

Study limitations

All studies included in the review were retrospective cohort studies which have inherited fundamental limitations such as recall and selection biases that put them at low level in the evidence hierarchy of effectiveness studies. Thus the review highlights the need for robust study-design; cluster-randomised study/prospective cohort study in-order to assess the efficiency of screening new entrants from TB endemic regions. Ideally a cost effectiveness study of the alternatives conducted alongside a cluster-randomised trial would be appropriate as this could influence the relationship between cost and effectiveness outcome ratios.

Conclusion

This review showed some evidence that active PoA screening of new entrants is worth doing. PoA screening more easily identified cases at high risk of infection and offered them treatment/chemoprophylaxis. However PS detected significant proportion of both active and latent cases.

Active PoA screening showed consistent clear benefit in reducing the period of infectiousness which is an opportunity to protect others from TB transmission with subsequent avoidance of hospital admissions with most relevance to TB control programmes in developed countries. However passive screening is marginally less costly both in screening an individual and preventing a case.

\section{References}

1-Reider H., Zellweger J., Raviglione M., Keizer ST. and Migliori GB. (1994). Tuberculosis control in Europe and international migration. European respiratory journal; 7: $1545-1553$.

2-Davies PD. (1995). Tuberculosis and migration: The Mitchell lecture 1994. Journal of the Royal College of Physicians London: $113-118$.

3-Dye C., Scheele S., Dolin P., Pathania V. and Raviglione MC. (1999). Global burden of tuberculosis: Estimated incidence, prevalence and mortality by country. 
JAMA; 282: $677-686$.

4-Menzies D. (2000). Tuberculosis crosses borders. International journal of tuberculosis and lung disease; 2 : S153 - S159.

5-Joint tuberculosis committee of the British thoracic society (2000). Control and prevention of tuberculosis in the United Kingdom: Code of practice. Thorax; 55: $887-901$.

6-Enarson D, Ashley MJ. and Grzybowski S. (1979). Tuberculosis in immigrants to Canada: A study of present day patterns in relation to immigration trends and birthplace. American review of respiratory diseases; 119: 11 $-17$.

7-McKenna MT., McCray E. and Onorato I. (1995). The epidemiology of Tuberculosis among foreign born persons in the United States, 1986 - 1993. New England journal of medicine; 332: 1071 - 1076.

8-Dahle UR., Sandven P., Heldal E. and Caugant DA. (2003). Continued low rates of transmission of mycobacterium tuberculosis in Norway. Journal of clinical microbiology; 41: 2968 - 2973.

9-California department of health services (2002). Tuberculosis control branch: Report on tuberculosis in California, technical report; California department of health services, Berkeley, California; 2004.

10-Catchpole M. (1995). Tuberculosis in England and Wales: Incidence of tuberculosis in London is rising against general recent trend. British medical journal; 311: 197.

11-Menzies D. (2003). Screening immigrants to Canada for tuberculosis: Chest radiography or tuberculin skin testing? Canadian medical association; 169 (10): 1035 $-1036$.

12-Bonvin L. and Zellweger JP. (1992). Mass miniature $\mathrm{X}$-ray screening for tuberculosis among immigrants entering Switzerland. International journal of tuberculosis and lung diseases; 73: 322 - 325.

13-Ormerod LP., Charlett A., Gilliam C., Darbyshire JH. and Watson JM. (1998). Geographical distribution of tuberculosis notifications in national surveys of England and Wales in 1988 and 1993: Report of the public health laboratory service, British thoracic society; Department of health collaborative group. Thorax; 53: $176-181$.

14-Callister MEJ., Barninger J., Thanabalasingam ST., Gair R. and Davidson RN. (2002). Pulmonary tuberculosis among political asylum seekers screened at Heathrow airport, London, 1995 - 1999. Thorax; 57: 152 $-156$.

15-Barnett DE. (2004). Infectious disease screening for refugees resettled in the United States. Travel medicine; 39: $833-841$.

16-Bothamley GH., Rowan JP., Griffith CJ., Beeks M., 671
McDonald., Beasley E., Van den Bosch C. and Feder G. (2002). Screening for tuberculosis: The port of arrival scheme compared with screening in general practice and the homeless. Thorax; 57: $45-49$.

17-Dasgupta K., Schwartzman K., Marchand R., Tennenbaum TN., Brassard P. and Menzies D. (2000). Comparison of cost effectiveness of tuberculosis screening of close contacts and foreign born populations. American journal of respiratory and critical care medicine; 162: 2079 - 2086.

18-Coker R. and Van Weezenbeek KL. (2001). Mandatory screening and treatment of immigrants for latent tuberculosis in the United States of America: Just restraint? The Lancet infectious diseases; 1: 270 - 276.

19-Dasgupta K. and Menzies D. (2005). Cost effectiveness of tuberculosis control strategies among immigrants and refugees. European respiratory journal; (25) 6: $1107-1116$.

20-World health organisation (2005). Global tuberculosis fact sheet 2005. Retrieved 22nd February 2008 from: http://www.who.int/tb/publications/2005/en/index. html

21-Dasgupta K., Schwartzman K., Marchand R., Tennenbaum TN., Brassard P. and Menzies D. (2000). Comparison of cost effectiveness of tuberculosis screening of close contacts and foreign born populations. American journal of respiratory and critical care medicine; 162: $2079-2086$.

22-Binkin NJ., Zuber PLF., Wells CD., Tipple MA. and Castro KG. (1996). Overseas screening for tuberculosis in immigrants and refugees to the United States, current status. Clinical infectious diseases; 23: 1226 - 1232.

23-Thomas RE. and Gushulak B. (1995). Screening and treatment of immigrants and refugees to Canada for tuberculosis: Implications of the experience of Canada and other industrialised countries. Canadian journal of infectious diseases; 6: 246 - 255.

24-Port health and medical inspection review report from the project team (2006). Retrieved October 20th 2008 from http://www.hpa.org.uk/web/HPAwebFile/ HPAweb_C/1194947399783

25-Veen J., Raviglione M., Reider HL., Migliori GB., Graf P., Grzemska M. and Zalesky R. (1998). Standardised tuberculosis treatment outcome monitoring in Europe. European respiratory journal; 12: 505 - 510.

26-Scottish Intercollegiate Guidelines Network (2004). Retrieved June 4th 2008 from http://www.sign.ac.uk/ guidelines/fulltext/50/checklist3.html

27-Lavender M. (1997). Screening immigrants for tuberculosis in Newcastle upon Tyne. Journal of public health medicine; 19(3): $320-323$.

African Health Sciences Vol 14 Issue 3, September 2014 